\title{
IDENTIDADE E SABEDORIA: A REFLEXÃO TEOLÓGICA COMO VERITATIS GAUDIUM
}

\section{IDENTITY AND WISDOM: THEOLOGICAL}

\section{REFLECTION AS VERITATIS GAUDIUM}

\section{Paulo Sérgio Lopes Gonçalves*}

\section{Resumo}

Objetiva-se, neste artigo, apresentar epistemologicamente a teologia como sabedoria que produz a alegria da verdade. Justifica-se este objetivo a necessidade de afirmar a identidade da teologia em meio ao contexto de pós-modernidade e de pluralismo teológico, para que não se torne uma ciência que utilize a identidade de outras ciências. Ao identificar a teologia como sabedoria, realça-se o seu vínculo com a revelação divina, que tem na sabedoria pré-existente o sujeito que realiza a criação, encarna-se na história humana e é o ápice de todo movimento revelador de Deus. Essa sabedoria é teorizada na teologia em sua relação com o mundo e com o ser humano, em toda a sua historicidade, dramas, tensões e perspectivas. Essa teologia sapiencial se torna, então, uma theologia mundi, que, concebida como scientia fidei, cujo assunto é Deus em sua relação com o mundo habitado pela humanidade, torna-se uma scientia Dei mundi. Para atingir o objetivo proposto, será decifrada teologicamente a revelação como fundamento da teologia, apresentada a configuração da teologia na relação entre Escritura e Tradição e mostrada a teologia como sabedoria ou, propriamente, como ciência sapiencial da fé revelada, que incide na história do mundo e do homem, para tornar-se contemporânea de cada época histórica.

Palavras-chave: teologia, sabedoria, revelação, scientia Dei.

* Doutor em Teologia pela PUG (Roma, Itália), Pós-doutorado em Filosofia pela UE (Évora, Portugal), Pós-doutorado em Teologia pela FAJE (Belo Horizonte, Brasil), docente-pesquisador do Programa de Pós-graduação Stricto Sensu em Ciências da Religião e dos cursos de graduação em Teologia e Filosofia, da Pontifícia Universidade Católica de Campinas-SP. E-mail: p aselogo@hotmail.com

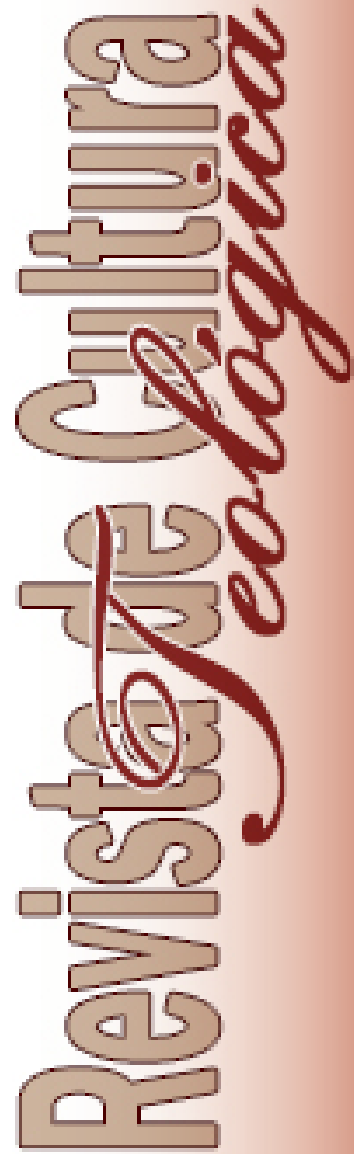

exto aprovado em 17.02.2020 e aprovado em 22.04.2020

Ano XXVIII - № 95 Jan - Abr 2020

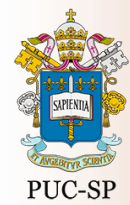

Programa de Estudos Pós Graduados em Teologia - PUC/SP 


\begin{abstract}
The objective of this article is to present epistemological theology as wisdom that produces the joy of truth. This objective is justified the need to affirm the identity of theology in the context of postmodernity and theological pluralism, so that it does not become a science that uses the identity of other sciences. By identifying theology as wisdom, its bond with divine revelation, which has in pre-existing wisdom, the subject who performs creation, embodies himself in human history, and is the culmination of every revealing movement of God. This wisdom is theorized in theology in its relationship with the world and with the human being, in all its historicity, dramas, tensions and perspectives. This wisdom theology then becomes a mundi theology that conceived as scientia fidei,whose subject is God in its relationship with the world inhabited by mankind, becomes a scientia Dei mundi. To achieve the proposed goal, revelation will be deciphered theologically as the basis of theology, presented the configuration of theology in the relationship between Scripture and Tradition, and shown theology as wisdom or properly as a wisdom science of the revealed faith, which focuses on the history of the world and man, to become contemporary of every historical time.
\end{abstract}

Keywords: theology, wisdom, revelation, scientia Dei

\title{
1. Introdução
}

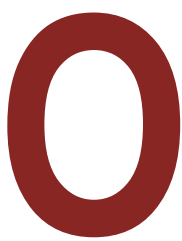

bjetiva-se neste texto apresentar epistemologicamente a teologia como sabedoria que produz a alegria da verdade. Justifica-se este objetivo o fato de que a constituição apostólica Veritatis Gaudium, escrita pelo Papa Francisco (2018) realça dois fatores contemporâneos que repercutem na concepção identitária da teologia: a pós-modernidade e o pluralismo teológico.

A categoria pós-modernidade, ainda que não seja passível de definição fácil e consensual entre os pensadores, pode ser concebida como paradoxo de continuidade e descontinuidade da modernidade, cujas marcas clássicas são o antropocentrismo e o cientificismo. Trata-se de uma categoria que continua a ter o homem moderno como centro da cultura e da sociedade, mas que ainda desenvolve a religião que poderia ter sido extinta conforme interpretações dadas à sentença nietzscheniana acerca da "morte de Deus", que implementa um conjunto de novas formas de comunicação, que ocasiona novas formas de relações entre os seres humanos, e que realça a dimensão estética tanto no âmbito da singularidade 
pessoal quanto no das diversas formas de coletividade humana.

O pluralismo teológico é uma realidade que tem se intensificado na era contemporânea, tendo realçado duas viradas epistemológicas pertinentes e relevantes: a antropológica e a hermenêutica. A primeira permite que a teologia desenvolva o seu assunto, que é Deus, tomando a realidade humana como espaço da própria revelação divina, concebida como encontro entre Deus e o homem. A segunda possibilita que a revelação seja compreendida e interpretada, sem que se esgote nas expressões denotativas de sua verdade. Ambas as viradas propiciam que a teologia, em sua clássica articulação entre auditus fidei e intellectus fidei, mantenha-se perseverante e fiel em seu assunto fundamental, de modo a atualizá-lo a cada época histórica.

Para atingir o objetivo proposto, expor-se-á a revelação como núcleo fundamental da teologia e a concepção de teologia como sabedoria oriunda da própria revelação e suas articulações na contemporaneidade histórica, no que se refere à epistemologia e à espiritualidade.

\section{A revelação como núcleo fundamental da teologia}

\subsection{A revelação veterotestamentária}

A teologia é concebida como ato teórico proveniente da experiência da revelação de Deus, cuja origem está no próprio Deus, que, gratuitamente, tomou a iniciativa de realizar sua autocomunicação aos seres humanos, servindo-se da história, em sua diferentes fases, culminando em Jesus Cristo, seu Filho, crucificado e ressuscitado, "Verbo que se fez carne" ( Jo 1,18) e "Salvador do mundo" (Jo 4,42). Esse movimento de revelação histórico-salvífica é constituído de etapas veterotestamentárias - patriarcal, exodal, profética, sapiencial e apocalíptica -, possui centralidade na aliança e na criação, culmina no novo testamento, em que se tem o cumprimento da promessa de vinda do "Filho do Homem", "Messias", "Salvador" e "Verbo de Deus", presente em Jesus Cristo, sua vida, paixão, morte e ressurreição, e sua relação com os apóstolos (COLLINS, 1981, pp. 21-24).

Essa revelação possui o primado da palavra de Deus, concebida como rea- 
lizadora de toda a criação (Gn 1,1-2,4a), interpeladora à constituição da aliança, profética para denunciar a idolatria e a consequente ruptura da aliança, e para chamar o povo à conversão - shub - e restabelecimento da referida aliança. Assim sendo, a palavra criadora é responsável pela edificação de toda a criação, responsável por dizer e fazer a luz, a água, a terra, os animais, os vegetais e o ser humano, que foi criado à "imagem e semelhança de Deus", depois de Deus ter insuflado - nefesh - as narinas do "boneco" de argila que fizera, dando vida ao ser humano - Adam. No alto do monte Sinai, a sarça ardente instigou a curiosidade de Moisés, que, aproximando-se dela, ouviu uma voz que dizia: "Não te aproximes daqui e tira as sandálias dos pés, porque o chão onde pisas é sagrado" (Ex 3,5). Tratava- se de uma afirmação do sagrado ou da potência misteriosa que se manifestava dialogando com Moisés, para constatar a revelação do Deus de Abraão, de Isaac e Jacó, com a sensibilidade de ver a aflição de seu povo, ouvir os seus clamores, conhecer as suas entranhas e descer - do monte - para libertar e conduzir esse mesmo povo para a terra de leite e mel (Ex 3,7-8). No diálogo, Deus se revela como "Aquele que É" e que terá esse povo que será libertado como seu povo da aliança (Ex 3,9-14). Nessa mesma perspectiva, situa-se a tradição sacerdotal de Gn 12,1-3, em que Deus afirmou sua aliança com Abraão, tirando-o de sua terra e de sua casa, para enviá-lo à terra mostrada por Ele, fazendo dele uma benção para aqueles que Deus abençoasse e uma grande nação por toda a sua descendência. A palavra deuteronômica (Dt 26,5-10) confirma a aliança mediante a terra e a descendência, rememorando os feitos de Deus em favor de seu povo, dando-lhe a identidade de um povo da aliança. ${ }^{1}$

A palavra de Deus também esteve presente nos profetas, considerados "homens de Deus" e defensores da aliança - berit - entre Javé e Israel ou Judá. Não obstante a especificidade contextual de cada profeta, o que há de comum entre eles é a idolatria, concebida como culto aos ídolos, que, por sua vez, não falam, não enxergam, não escutam e não se movem por poder próprio, mas tão somente pelo poder que lhes é dado por seus respectivos devotos (RICHARD, 1985, pp.

1. GONÇALVES, P.S.L. A Aliança entre Javé e Israel como paradigma para a efetividade da justiça, in BORGES DUARTE, I. (org.). Fios de Memória. Liber Amicorum para Fernanda Henriques. Lisboa: Húmus, 2018, p. 420-422; PASTOR, F.A. A lógica do Inefável. Aparecida: Santuário, 2012, p. 175-181. 
9-35). A idolatria possui caráter tridimensional (religioso, econômico e político). O primeiro refere-se ao ato de abandonar a Javé e a praticar o culto aos ídolos, que são devotados pelo poder humano, o que os caracteriza como produtos de mãos humanas. O segundo corresponde à exploração econômica que o povo sofre, sendo vítima da injustiça, principalmente os pobres e, dentre eles, particularmente os órfãos e as viúvas, que estavam espalhados pelas ruas de Jerusalém. O terceiro é a descaracterização do javismo como instância que levava a cabo o nacionalismo político e a implementação de uma política internacional que retirava a soberania de Israel e Judá, encontrando na idolatria religiosa a sua legitimação e plausibilidade que promoviam a devoção aos ídolos e a continuidade da dominação internacional sobre o povo (GONÇALVES, 2018, pp. 427-427).

A palavra profética é marcada por características pessoais do próprio profeta: humildade e retidão solidária aos pobres - Elias e Eliseu -, firmeza na denúncia - Amós e Miquéias -, fidelidade e misericórdia - Oseias - (Os 2,4-25) e angústia por conta da infidelidade do povo aliança - Jeremias e Ezequiel. Desse modo, os profetas proclamam uma palavra de contraposição à idolatria, rememorando a aliança como forma de chamar o povo à conversão e de afirmar a soberania de Deus (Os 2, 4-25), proclamando a justiça e a paz (Am 2,6-16), denunciando a idolatria e anunciando a vinda messiânica de Deus (Is 28,14-29), proclamando o futuro novo do povo - por meio de linguagem metafórica imbuída de esperança (Ez 37,1-14), anunciando a esperança de restauração da aliança mesmo em meio à angústia e a tensões históricas (Jr 31,31-34), e proclamando a nova criação (Is $41,1-7)$ e a utopia do sonho de Deus, em que há harmonia no povo da aliança e, a partir dela, a comunhão de todos os povos da terra (Is $65,17-24){ }^{2}$

A palavra reveladora está presente também na obra histórica deuteronomista, uma literatura que teve origem ainda no tempo do rei Josias - que é o monarca que unificou o culto em Jerusalém para pôr fim à idolatria e manter o povo religiosamente fiel a Javé - e que ganhou grande corpo durante o exílio da Babilônia (586-536 a.C.). Trata-se de uma literatura escrita por autores que, diante da si-

2. SOARES, S.A.G., Reler os profetas (notas sobre a releitura da Profecia Bíblica), in Estudos Bíblicos, Petrópolis, v. 4, p. 8-32, 1986; CROATTO, J.S. A estrutura dos livros proféticos. As releituras dentro do corpus profético, in Ribla, Petrópolis, v.35/36, p. 7-27, 2000. 
tuação do exílio, desejavam compreender o que havia acontecido com a relação entre Judá e Javé, pois a aliança poderia desaparecer à medida que, exilado, o povo estava longe de sua terra e com a ameaça de perder a sua descendência, já que os judeus poderiam se misturar culturalmente com os babilônios. Afinal, Deus abandonou o seu povo ou o povo abandonou a Deus? Para responder a essa indagação, os autores realizam uma análise teológica da história de Israel e Judá, desde a entrada na terra prometida - de leite e mel - para toda a descendência, passando pela confederação das tribos, a constituição da monarquia e as crises que derrubaram o reino do Norte e o reino do Sul, trazendo à tona a causa fundamental das derrocadas: a idolatria. Por isso, essa literatura se aproxima da literatura profética, ao constatar que o povo abandonou a Javé para cultuar ídolos, que os reis foram os responsáveis pelo mal feito aos olhos de Javé, mas que Deus, em vez de destruir o seu povo, chamou-o à conversão - shub - para restaurar a aliança. Essa restauração ocorrerá mediante a observação da palavra da lei, que rememora a aliança e organiza o povo, para que, cumprindo-a, seja fiel a Deus como povo da aliança. ${ }^{3}$

A revelação divina acontece também mediante a palavra sapiencial, cuja literatura - Sabedoria, Salmos, Jó, Provérbios, Eclesiastes, Cântico dos Cânticos e Eclesiástico - situava-se no contexto da teologia da retribuição, que afirmava que a retidão a Deus era garantia para o sucesso no trabalho e na constituição familiar, a prosperidade social e religiosa e a vida longeva. No entanto, essa teologia não conseguia explicar a morte do jovem fiel a Deus, o sofrimento do inocente, os limites dos projetos da vida, as angústias diante das injustiças, os dramas familiares na organização do povo, as injustiças nos tribunais e tantos outros dramas humanos cotidianos e do próprio povo da aliança. Assim sendo, a literatura sapiencial concebe a sabedoria como a experiência que os seres humanos fazem de Deus, mediante a sua experiência de vida, marcada por sua história imbuída de tensões, dramas e esperanças. Por isso, os temas fundamentais são a morte, o sofrimento, a angústia, o tempo, a criação, os dramas, a relevância da

3. SICRE, J.L. As tradições históricas de Israel. Introdução à história do Antigo Testamento. Petrópolis: Vozes,1999; KLEIN, R.W. Israel no exílio. Uma interpretação teológica. São Paulo: Paulinas, 1990, p. 34-55; SMITH, M.S. O memorial de Deus. História, memória e a experiência do divino no Antigo Israel. São Paulo: Paulus, 2006, p. 54-70. 
família para a constituição do povo e a esperança. ${ }^{4}$

Desse modo, a palavra reveladora se identifica com a sabedoria à medida que se constitui de pré-existência junto de Deus, é mediadora da criação, apresentando-se como mestre de obras da criação divina (Prv 8,14-22). Essa palavra sapiencial não é indiferente à morte do jovem fiel a Deus, mas é a realizadora da justiça divina à medida que os "justos estão nas mãos de Deus" ( $\mathrm{Sb}$ $3,1)$, nem tampouco é insensível ao sofrimento do inocente Jó, ainda que tenha se revoltado com Deus, em função de ter-se tornado vítima do sofrimento e da desgraça, apesar de sua fidelidade. A experiência que Jó faz de Deus, ao longo de sua história dramática, leva-o à percepção de que Deus não é alheio ao sofrimento, mas compassivo e capaz de sofrer junto com o sofredor vitimado. Diante das angústias trazidas pela vida em sua historicidade dramática, em que tudo se torna vaidade, visto que há vaidade das vaidades ( $\mathrm{Ecl} 1,1)$, a palavra sapiencial revela Deus no tempo experimentado pelo ser humano, pois para "tudo o que está debaixo do firmamento e sobre a terra há o seu próprio tempo" (Ecl 3,1). Então, há um tempo para cada coisa: nascer, morrer, falar, calar, dormir, acordar, trabalhar, descansar, plantar, colher, guerrear e promover a paz $(\mathrm{Ecl} 3,1-8)$. Se há um tempo para cada coisa, então por que o homem se excede ao falar, ao colher, ao trabalhar, ao descansar e ao calar? (Ecl 3,9). Esse ser humano é também capaz de expressar o seu amor, edificando a relação virtuosa e mostrando a aliança do povo com Deus, através da plenitude do amor humano, em que a amada e o amado se encontram para amar, porque nada pode terminar com o amor ( $\mathrm{Ct} 2,8-3,5)$. Os salmos exprimem diversas situações nas quais Deus se revela como palavra sapiencial que perdoa (S1 50), acalma, conforta, consola, pastoreia (S1 22), proporciona o temor que traz a felicidade ( $\mathrm{S} 1$ 127) e mostra toda a sua soberania em ser o "Deus dos deuses" (S1 150).

A palavra reveladora se apresenta também em perspectiva apocalíptica, em que diante das aflições do povo, devido ao império alexandrino que buscou hele-

4. ZIENER, G. A sabedoria do oriente antigo como ciência da vida. Nova compreensão e crítica de Israel à sabedoria, in SCHREINER, J. (org.). Palavra e Mensagem. São Paulo: Paulinas, 1978, p. 363-381; GLASSER, E. O processo da felicidade por Coelet. São Paulo: Paulinas, 1975; RAVASI, G. Cântico dos Cânticos. São Paulo: Paulinas, 1988; TERRIEN, S. Jó. São Paulo: Paulus, 1994. 
nizar os judeus mediante um processo de imposição militar e cultural, a resistência se manifesta através da esperança que antecipa o futuro para o presente. Essa antecipação se efetiva através da afirmação da categoria Reino de Deus, espaço da ressureição dos justos e da soberania de Deus, que faz valer a sua justiça, efetua a redenção em todo o universo e irradia esperança de que a opressão, a injustiça, as trevas e os males não prevalecerão, porque o reinado de Deus indica a sua vitória para sempre. ${ }^{5}$

\subsection{A revelação neotestamentária}

No âmbito do novo testamento, a palavra reveladora apresenta heranças veterotestamentárias, trazendo à tona o cumprimento da história da salvação em Jesus Cristo, revelação plena, completa, perfeita e definitiva de Deus. A palavra reveladora tornou-se anúncio da salvação - kerygma -, ensinamento catequético - didaskália -, e testemunho - martyria - da fé revelada em forma de serviço - diakonia -, realizado na e pela communitas fidelium. Nesse processo, há uma momento de transmissão oral da revelação que dá espaço para os escritos neotestamentários, cujo início se efetiva na primeira carta de Paulo aos tessalonicenses (da qual surgiu o corpus paulino - anos 50-60 d.C. -, constituído de literatura paulina e deutero-paulina), e, em seguida, algumas cartas apostólicas - como a de Tiago - denotativas da prática da fé cristã, e os evangelhos de Marcos no ano 70 d.C., de Mateus em 75 d.C., a obra lucana - evangelho e Atos - no ano de 80 d.C., a literatura joanina e o apocalipse em 90 d.C, e outras cartas apostólicas - como a primeira carta de Pedro e a carta aos hebreus - no ano 100 d.C. À medida que o kerygma foi acontecendo, acompanhado da catequese, do serviço e da formação das comunidades, ocorreu um processo de retroação hermenêutica que partiu do Cristo ressuscitado, identificado como crucificado, missionário itinerante, imagem visível do Deus invisível $(\mathrm{Cl}$ 1,15), Filho do homem - Filho de Deus - (Mc 8,31), Messias que traz à história a justiça do Reino de Deus (Mt 1,21-25), o Salvador que fora prometido pelos profetas e que veio anunciar o ano da graça do Senhor (Lc 4,16-22), o Verbo que era Deus, estava com Deus,

5. KIPPENBERG, H.G. Religião e formação de classes na antiga Judeia. São Paulo: Paulinas, 1988; RUSSEL, D.S. Desvelamento divino. Uma introdução à apocalíptica judaica. São Paulo: Paulus, 1997. 
habitou entre nós e se fez carne (Jo 1,1-3), o mediador e o cordeiro pascal (Hb 10,1). (SHREINER - DAUTZENBERG, 2004).

Conforme a perspectiva paulina, Cristo é a palavra que revela o mistério de Deus, sempre amoroso, cujo desígnio salvífico é universal. O mistério é, então, o plano divino da salvação, oculto ou absconditus desde toda a eternidade e, agora, revelado, pelo Deus que estabeleceu a Cristo como o centro da história da salvação, constituindo-o pela sua encarnação, morte e ressurreição, único princípio de salvação tanto para os gentios como para os judeus, cabeça de todos os seres, anjos e homens. Trata-se de um plano divino total concentrado em Cristo, com suas riquezas insondáveis (Ef 3,8), seus tesouros de sabedoria e ciência ( $\mathrm{Cl}$ 2,2-

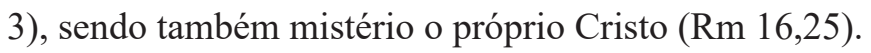

Nos evangelhos sinóticos, Jesus é aquele que ensina (Mc 1,22), prega (Mc 1,39), percorre as aldeias ensinando (Mc 6,6), anuncia a boa-nova no templo (Lc 19,47). Então, Jesus proclama e realiza personificadamente a novidade inaudita do reino de Deus. Seu ensinamento ou instrução detalha o mistério da fé e os respectivos preceitos morais, tornando juntos e fazendo parte do mesmo movimento de revelação, do anúncio do evangelho e da catequese acerca do conteúdo revelado. Ele é, assim, concebido como pregador e doutor, que dá continuidade à tradição profética na proclamação da palavra, pois anuncia a boa-nova do Reino e introduz a penitência para acolhê-lo (Mt 4,17; Mc 1, 14-15).

Ao pregar o evangelho - que é Ele mesmo -, Jesus associa o Messias à obra de evangelização junto aos pobres, dando vista as cegos, libertando os prisioneiros e anunciando o ano da graça do Senhor (Lc 4,16-20). A despeito de não reivindicar título qualquer, Jesus simultanemaente se aproxima (Mc 4,11; Lc 13,33 ) e ultrapassa os profetas em sua pregação, sendo maior do que Jonas (Mt 12,40), Moisés e Elias (Mc 9,2-10) e João Batista (Lc 7,18-23). Assim sendo, Ele leva à perfeição a lei e os profetas $(\mathrm{Mt} 5,17)$ e ainda chama outras pessoas à participação em sua missão (Mc 3,14): pregar o evangelho e o reino de Deus a todas as pessoas (Mc 13,10) e em todo o mundo (Mt 24,14) e curar os enfermos (Lc 9,2; Mt 10,7-8).

$\mathrm{Na}$ condição de doutor, Cristo foi chamado de rabbi (Mc 9,5), encontrou-se 
com os doutores ainda adolescente (Lc 2,46-47) e passou parte de sua vida ensinando publicamente na sinagoga (Mc 1,21), na montanha (Mt 5,1-2) e até mesmo no templo (Mc 12,35). Jesus ensianava ocosialmente à medida que respondia as perguntas, corrigia as atitudes e apresentava os princípios fundamentais, tais como pobreza, humildade, caridade. Além disso, ensinava também sistematicamente, manifestando o sentido das parábolas (Mt 13,10-12), esclarecendo o sentido de sua paixão-morte-ressurreição (Mc 8,31) e transmitindo a sua doutrina tanto aos discípulos quanto às multidões (Mt 13,1-53). As características do ensinamento de Cristo são realizadas com autoridade de conhecimento da verdade (Mc 1,22: Lc 4,31-32), com sabedoria de mestre (Mt 23,10) e com autoridade divina, de modo que seus ensinamentos perpetuam para sempre (Mt 24,35). No ensinamento de Cristo, está a afirmação de que Ele é o Filho único do Pai, herdeiro de Deus (Mc 12,6), a quem o Pai tudo confiou. Essa filiação dá consistência à sua autoridade de ensinar, de agir e de transmitir o amor do Pai aos seres humanos (Mc 1,11; Mt 7,21). Ao ser Filho, Cristo é perfeito revelador e conhecedor do Pai, cujo conhecimento comunica a quem bem lhe apraz, especialmente aos discípulos, que são os que possuem essa graça (Mc 4,10-12). O Pai também revela o Filho aos pequenos (Mt 17,16) e aos pobres (Mt 31, 25-46) e, desse modo, revela o próprio mistério divino.

Na perspectiva dos Atos dos Apóstolos, a efetividade da palavra reveladora acontece no testemunho apostólico de Cristo, realizado através da relação pessoal com Jesus Cristo, do anúncio kerygmático, da formação das comunidades, da celebração da fé, do ensinamento catequético e da firmeza da fé, atestada em forma de martírio. Ao testemunharem a ressurreição, os apóstolos se situam diante do acontecimento essencial, que dá sentido à vida apostólica e de toda a comunidade cristã (At 1,22; 5,30-31). São também testemunhas de tudo o que viram e ouviram de Cristo (At 4,20), de seus atos e sua doutrina (At 1,1), de toda a vida desde o batismo até a ressurreição (At 10,39). Testemunharam a obra de salvação inaugurada na morte e ressurreição de Jesus Cristo (At 5,31) e têm o Espírito Santo que receberam com grande poder (At 4,33) como garantia desse testemunho (At 1,8), com coragem e perseverança (At 4,8; 6,10), com instrução (At 4,13), com assistência em sua missão, resistência à perseguição e entrega 
ao martírio por fé em Cristo (At 4,8; 5,41; 6, 1-15). Tetsemunhar é a atividade apostólica, principiada pela professio fidei, passando pela compreensão da fé e por sua transmissão kerygmática, litúrgica, catequética e ético-moral.

$\mathrm{Na}$ literatura joanina, a palavra reveladora é o Logos que era Deus, estava com Deus, habitou kenoticamente na história humana, fazendo-se carne - sarx em grego e basar em hebraico -, no sentido de ser humano em sua constituição integral de corpo, alma - psiché - e espírito - pneuma. Esse Logos é mediador de toda criação, de toda a vida, e identificado com a sabedoria divina ( $\mathrm{Sb}$ 7-8), que é mediadora de toda a criação ( $\operatorname{Prv} 8,14-22)$, que tudo vê e penetra ( $\mathrm{Sb} 9,11)$, tudo governa ( $\mathrm{Sb} 8,1)$, instrui os homens $(\mathrm{Sb} 9,11)$ e assiste-os ( $\mathrm{Sb} 9,10)$.

O autor do texto recorda também que há uma anterioridade do Logos em Deus, porque era e estava com Deus. O Logos possui uma história intratrinitária, pela qual se apresenta como luz verdadeira que ilumina todo homem, sendo também o mediador da criação, tornando tudo vida. Ele é, desse modo, o sacramento de Deus, a palavra substancial de Deus, o Filho único do Pai (Jo 1,18). Ao fazer-se carne, a Palavra tornou-se mensagem divina, narrando à humanidade, em termos e proposições humanas, os segredos ao Pai, principalmente o mistério de seu amor por seus filhos. Constata-se também nessa textualidade joanina que três elementos fazem de Cristo o perfeito revelador do Pai: sua preexistência como Verbo de Deus (Jo 1,1-2), sua encarnação (Jo 1,14) e sua intimidade de vida permanente com o Pai, antes e depois da encarnação (Jo 1,18). Em outras palavras, Cristo é a palavra encarnada, o Filho que vive no seio do Pai, o perfetio revelador que tem sua missão de revelação fundamentada na própria vida no seio da Trindade.

Nessa intimidade com o Pai, Cristo é Palavra de Deus que fala, testemunha perfeita e fielmente sobre o Pai (Jo 1,18), declarando o que viu e ouviu do Pai. Seu testemunho é depoimento público no vasto processo que o opõe ao mundo. Em sua condição de testemunha qualificada, Cristo fala e é, ao mesmo tempo, a Palavra de Deus (Jo 1,1-2), o Filho que conhece o Pai, porque vem junto Dele (Jo 6,46; 7,29). Por sua vez, o Pai também conhece e testemunha a presença do Filho (Jo 10,15), pois o ama e entregou todas as coisas em suas mãos (Jo 3,35), 
confiando-lhe poder para a realização de suas obras ( Jo 10,25). Por isso, o Filho e o Pai estão entrelaçados um no outo (Jo 17,21), resultando que a palavra de Jesus Cristo seja a afirmação de quem viu e ouviu pessoalmente o que veio do Pai (Jo 3, 32; 8,38); uma palavra que é luz (Jo 1,8) e verdade (Jo 14,6), que testemunha as maravilhas do Pai, operadas por meio Dele e na ação do Espírito Santo (1Jo 5,10-11).

\section{A relação entre Escritura e Tradição na configuração da teologia}

A relação entre Jesus Cristo e os apóstolos é denominada de revelação fundante ou revelação direta, encerrando-se na morte do último dos apóstolos e possibilitando a efetivação da revelação continuada, cuja característica fundamental é a de transmitir a revelação fundante, por diversas formas, nos diversos lugares, constituindo a tradição cristã (O'COLLINS, 1987, pp. 125-135).

Por se constituir no testemunho fundamental da revelação, a Escritura possui o núcleo crucial do encontro dos apóstolos e membros da communitas fidelium com Jesus Cristo, efetuado mediante um processo originariamente de transmissão oral da experiência fundante do cristianismo e, posteriormente, de produção escrita, cuja potência está no fato de que é revelação direta de Jesus para com os apóstolos, encerrada na morte do último dos apóstolos. Dessa experiência fundacional da revelação, tem-se a Tradição apostólica, que consiste em ser o conteúdo da revelação que propicia um movimento de transmissão dessa mesma revelação, ao longo da história, possibilitando a formação de tradições, que se identificam por serem espaços de renovação da supracitada Tradição apostólica (CONGAR, 1983). Assim sendo, a tradição é a fiel transmissão da Palavra de Deus, testemunhada pelos profetas e pelos apóstolos nos cânones da Escritura e na liturgia - leiturgia -, no testemunho - martyria e no serviço - diakonia eclesial.

Do movimento da revelação emerge a fé, que é acolhida e resposta à Palavra de Deus, apresentando o ser humano como "ouvinte da Palavra" proferida pelo Deus misterioso, santo e inefável (RAHNER, 1997. pp. 8-28). Não há fé sem escutar a palavra de Deus, revelada em Cristo (Rm 10,17), anunciada pelos apóstolos (Ef 2, 20-22), cuja transmissão remete ao entregar-se a Deus mediante a fé, 
de forma obediente para acolher a revelação, que torna o ser humano salvo (2Tm 2,13) e livre (Jo 8,32) para viver totalmente em Cristo (G1 5,1). A fé é, então, a experiência de Deus que corresponde ao conhecimento acerca Dele, enquanto a revelação dá acesso à verdade de Deus que salva os seres humanos $(2 \mathrm{Tm} 2,13)$, apresentando-se com Deus uno, criador e Senhor da história e do universo ( $\mathrm{Sb}$ 13, 1-9). No entanto, somente através da fé, torna-se possível conhecer a Deus, revelado plenamente por meio do evento Jesus Cristo, como Deus que, interiormente em seu mistério, é Pai, Filho e Espírito Santo. A fé é compreendida nas dimensões de fides qua e fides quae, ainda que ambas, mesmo sendo distintas, não podem nem devem se separar uma da outra. A fides qua é correspondente ao ato de professar, celebrar e testemunhar a fé em communitas fidelium na koinonia do Espírito Santo (2Cor 13,13). Por sua vez, a fides quae é o conteúdo do que é professado, celebrado e testemunhado, enquanto é o evangelho proclamado e ensinado para ser vivido pelas pessoas que creem e por todas as pessoas de boa vontade.

A fé revelada possui, dessa maneira, a dimensão da inteligência, além das dimensões da doxologia e do testemunho. A inteligência da fé consiste em uma instância de compreensão e de interpretação da fé para apontar o sentido dessa mesma fé à existência humana. Essa inteligência não se desvincula do ato de crer e, tampouco, do ato de testemunhar a fé, durante o processo de conhecimento de Deus. Por isso, a inteligência está presente na catequese, que é o ensino da Igreja acerca do conteúdo da revelação e da fé, na liturgia que celebra doxologicamente a fé, nas afirmações dogmáticas que garantem a verdade revelada da fé e na ação pastoral e vivencial da Igreja ao longo de sua história, em que é efetivada a prática da fé. Resulta, então, o grande patrimônio da tradição cristã, que se apresenta na patrística eclesial - tanto do oriente quanto do ocidente -, nas formas do simbolifidei, nos dogmas - tanto os que foram proclamados em concílios quanto os que foram proclamados pelos papas -, e nas outras formulações teológicas e morais presentes no magistério eclesiástico, amparadas pelo sensus fidei fidelium.

No entanto, a inteligência da fé que se apresenta na teologia é a fé que procura compreender - fides quaerens intelectum - e está dotada de dimensão racional. Desse modo, a teologia é a razão compreendendo a fé à luz da fé, ha- 
vendo evidente articulação entre ratio e lumen fidei para que a teologia se constitua como ratio fidei. Nesse sentido, a teologia é scientia fidei, por se apropriar da fé revelada e constituir-se como teoria para compreender de modo racional e sistemático a verdade salvífica de Deus. Por isso, a teologia pode também ser denominada de scientia Dei, pois o assunto ou, propriamente, o objeto da teologia é Deus. Porém, como Deus não pode ser objeto à maneira de um objeto de alguma ciência empírica, então a teologia se concentra nos elementos essenciais da revelação, pelos quais se escuta a fé: a Escritura e a Tradição (PASTOR, 2015, pp. 33-50).

Conforme apresentou-se acima, a Escritura é o testemunho escrito da revelação de Deus, em suas etapas e seu ápice, que é Jesus Cristo, inclusive em sua relação com os apóstolos, da qual surgiu a Tradição apostólica. Por isso, a Escritura é chamada de "alma da teologia", (DV 24) por se constituir o fundamento da revelação e da fé, e o espaço de explicitação da Palavra viva de Deus, revelada aos seres humanos. Por sua vez, a Tradição apostólica, por ser de fundamental importância para compreender a relação de Cristo com a Igreja, tornou-se lex orandi - norma da oração -, lex credendi - norma da fé - e lex vivendi - norma de vida e testemunho da fé -, de modo que a Tradição é sempre viva e vital para a communitas christiana no decorrer da história. Nesse sentido, a Tradição apostólica progride na vida eclesial, insere-se nas diferentes formas culturais do cristianismo e nas várias formas de linguagem, de modo que se torna atual produzindo tradições, que sejam consoantes à significação originária da fé revelada. Desse modo, a Tradição, que é sempre potenciada pelo Espírito Santo, possui diversos componentes, dentre os quais se destacam o constante estudo renovado da Escritura, o culto litúrgico e seu desenvolvimento ao longo da história, a catequese que alimenta e faz a comunidade crescer na fé, o amor prático a Deus e aos seres humanos, o ministério eclesial em suas diversas configurações e o serviço do magistério à palavra de Deus (BOFF, 1998).

Ao possibilitar a emergência das tradições em seu dinamismo vital, a Tradição realça o valor do ecumenismo para levar a cabo a catolicidade da Igreja, propiciando movimentação para que haja unidade da Igreja de Cristo. Por isso, é tão importante para a teologia o sensus fidelium, definido como "o senti- 
do sobrenatural da fé - sensus fidei - de todo o povo" (LG 12). Resulta, então, que todo o povo de Deus seja sujeito da fé, que mediante a potência do Espírito Santo afirma e anuncia a palavra de Deus. Desse magistério presente no povo de Deus, emerge o magistério eclesiástico, que, em sua vivacidade, interpreta a fé revelada e zela para que a teologia tenha o primado da palavra de Deus e ajude o magistério a proclamar e interpretar autenticamente essa mesma fé, mediante o estudo sério e aprofundado da revelação e da fé (DV 10). Não obstante que possa haver tensões entre magistério eclesiástico e teologia, é mister afirmar que essas tensões são passíveis de servirem como instrumentos de auxílio para que o referido magistério e os teólogos estejam sempre em relação de mútua colaboração e complementaridade.

O caráter nuclear da revelação na teologia a vincula com o mundo, não para condená-lo nem para imitá-lo e reproduzi-lo, mas, para ver nele, a revelação histórica de Deus junto aos seres humanos. Por isso, a teologia não se faz sem a história do mundo situado pela humanidade, marcada pela diversidade de povos e culturas e por sua dramática situação de tristezas, angústias, alegrias e esperanças (GS 1). É neste mundo histórico, efetivamente real, em que se encontram as situações mais profundas da existência humana, tanto no âmbito pessoal como no coletivo, principalmente a dramática situação de inumanidade de inúmeras pessoas que vivem a pobreza, compreendida como carência de meios econômicos e sociais de sobrevivência, em função do sistema social, econômico e político denotativo da exploração, da desigualdade, da "violência institucionalizada", 6 da "injustiça estrutural"7 e de tantas formas que promovem a "morte prematura dos pobres" (GUTIÉRREZ, 1998), que a teologia desenvolve o seu assunto: Deus.

Resulta, dessa maneira, que a teologia compreenda os "sinais dos tempos", (SEGUNDO, 1990, pp. 443-446), concebidos como acontecimentos históricos,

6. EPISCOPADO LATINOAMERICANO, MEDELLÍN - 1968. La Iglesia en la actual transformación de América Lartina a la luz del Concilio, n. 2, II, 16, in Conferencias Generales: Río de Janeiro, Medellín, Puebla, Santo Domingo. Documentos Pastorales: Introducción, Textos, Indice Temático. Santiago del Chile: San Pablo, 1993, p. 82-223.

7. EPISCOPADO LATINOAMERICANO, PUEBLA- 1979. La evangelización en el presente y en el futuro de América Latina, n.562, in Conferencias Generales: Río de Janeiro, Medellín, Puebla, Santo Domingo. Documentos Pastorales: Introducción, Textos, Indice Temático. Santiago del Chile: San Pablo, 1993, p. 225-464. 
que, em função de seu impacto, definem um período e dão expressão a determinadas exigências da humanidade da respectiva época histórica. Trata-se de uma categoria que traz à tona a historicidade do mundo em sua dramaticidade, da Igreja em sua efetividade pastoral e do próprio Deus, à medida que é encontrado na própria história do mundo com suas marcas dramáticas (BOFF, 1979).

Ao situar-se no mundo, para falar de Deus a partir desse mundo, a teologia tem seu discurso universal contextualizado na epocalidade histórica, cultural, religiosa e social, de modo a emergir a pluralidade de teologias, que possibilitam que a revelação de Deus seja concebida na política como perspectiva para pensar essa mesma revelação, nos contextos históricos dos povos e culturas, nas situações de gênero, no pluralismo religioso, na modernidade e pós-modernidade, no clamor pela libertação, na perspectiva da descolonização e na emergência urgente da ecologia (TAMAYO-ACOSTA, 2011). Essa pluralidade de teologia não significa que não há unidade epistemologia entre as diversas formas de fazer teologia, ao contrário, essa unidade existe à medida que a teologia é concebida como sabedoria, que inclui a experiência de vida dos seres humanos, a formulação científica do falar de Deus e a fidelidade à verdade oriunda do próprio Deus.

\section{A Teologia como Sabedoria}

\subsection{Características da Sabedoria}

A concepção da teologia como sabedoria é a configuração da teologia fundamentada na revelação de Deus, compreendida como autocomunicação de Deus aos seres humanos, servindo da história como campo próprio da revelação. Conforme o exposto acima, em suas diferentes etapas, a revelação é a presença da própria sabedoria de Deus, que não obstante um modo nominalmente próprio de se apresentar na literatura bíblica, faz-se presente em toda a história da salvação, ainda que tenha sido denominada como palavra reveladora. Desse modo, vale recordar alguns elementos que são próprios da sabedoria bíblica e que hão de estar presentes na teologia concebida como scientia fidei e scientia Dei, para que sirvam de fundamentos da configuração científica da teologia e de sua espiritualidade teologal. Esses elementos são: temor de Deus, pré-existência criacional, humildade, historicidade, compaixão e orientação. 
Considerando que o conceito bíblico de sabedoria corresponde à experiência que o ser humano realiza de Deus, através da experiência da vida em sua intensidade, o temor de Deus é o reconhecimento de que Deus, em sua revelação é semper maior, onisciente, onipotente e onipresente, mas sempre próximo ao ser humano em sua história vital. O ser humano reconhece essa maioridade de Deus à medida que tem consciência de que a autocomunicação divina é componente essencial do próprio mistério de Deus, que não se confunde com segredo, mas se apresenta como o que está escondido que se revela e, quando se revela, não esgota o que ainda continua escondido. Nesse sentido, o temor implica reconhecer simultaneamente que Deus é inexaurível e revelador em seu mistério, tendo o ser humano como seu interlocutor e partner da aliança. Por sua vez, o ser humano responde à revelação com confiança em Deus, em sua autocomunicação e providência, realizadas na história.

O mistério está historicamente revelado na sabedoria pré-existente, que estava junto de Deus sendo mediadora de toda a criação, responsabilizando-se por todas as coisas criadas. A entrada na história dessa sabedoria foi realizada através de um movimento de kenósis, denotativa da humildade da sabedoria, que habita toda a criação. Essa sabedoria, na fé cristã, está personificada em Jesus Cristo e assume amorosamente a carne humana em todas suas dimensões histórico-sociais, incluindo o ensinamento da palavra sapiencial, o sofrimento e a morte. Trata-se de uma sabedoria que é educativa e orientadora ao movimento da revelação através da fé que opera na caridade - que é o amor em movimento - e suscita a esperança que vem do próprio Deus. Ao entrar na história para educar os seres humanos, essa sabedoria assume compassivamente o sofrimento humano, propiciando que, por seu intermédio, Deus sofra junto com os seres, como expressão de seu amor pela humanidade. Essa compaixão é radical à medida que a sabedoria personificada de Deus - Jesus Cristo - morre na cruz, que se torna loucura para este mundo e instrumento da obra redentora e salvífica realizada sapiencialmente. A compaixão no sofrimento e na morte está radicalizada em seu valor na ressurreição de Jesus, que é a realização da própria esperança escatológica, em que a vida adquiriu sentido pleno para a existência humana (MOLTMANN, 2007, pp. 187-206). 
Ao assumir compassiva, misericórdia e amorosamente o pathos do mundo, a sabedoria é o próprio modo de Deus se revelar aos seres humanos na história. Assim sendo, essa sabedoria se configura na teologia, tornando essa scientia fidei ou scientia Dei, cujo positum de sua onticidade científica é a fé em articulação com a história do mundo, em que os seres humanos vivem ou ainda a "casa comum" habitada por todas as criaturas. Essa ciência sapiencial é, então, uma theologia mundi, que trata de Deus - que é assunto próprio da teologia - em sua relação com o mundo, concebido em sua estética dramática, em seu vale de lágrimas e no gemido das dores de parto, em que o bom combate é combatido e em que a esperança não decepciona.

\subsection{Teologia: ciência sapiencial da fé revelada}

Em sua condição de ciência sapiencial, a teologia se insere no mundo em que há pluralidade religiosa e cultural, economia desequilibrada e denotativa de iniquidade, política estruturada em torno de interesses próprios de grupos e pessoas, amparando a pobreza como fruto da injustiça, situações sociais de violência e de morte prematura. Imbuída do conteúdo da fé revelada, a teologia se apropria do evangelho da vida e o relaciona ao pathos do mundo, utilizando-se de mediações teóricas, para que seu complexo teórico seja efetivamente científico. Isso significa que a fé há de estar articulada com a razão e com a experiência histórica de vida dos seres humanos, compreendidos em cada época histórica, a fim de que a teologia seja efetivamente um discurso contemporâneo sobre Deus (METZ, 2007, pp. 17-45).

Historicamente, desde os primórdios do cristianismo, a filosofia tornou-se um substrato teórico da teologia, obtendo o título de ancilla, que, reconfigurada, compreende-se como partner, à medida que se constitui como um momento da própria elaboração teológica. Através da filosofia, concebida epistemologicamente como "ciência ontológica" e como metafísica, a teologia se apropriou de categorias fundamentais para o seu complexo teórico, tais como substantia, persona, pericórese, creatio ex nihilo. Em suas diversas formas históricas, a teologia teve a presença da filosofia para decifrar o significado do ser humano, do mundo e de Deus, ainda que seja possível admitir a perspectiva heideggeriana de que a 
metafísica tenha privilegiado o ente e se esquecido do ser, embora também seja permitido afirmar rahnerianamente que a filosofia deu à teologia uma "metafísica do ser", em que é decifrada a presença histórica do ser no homem e no mundo na relação com Deus (GONÇALVES, 2011, pp. 23-58).

Essas duas posições denotam uma questão contemporânea incisiva para a teologia: a crise da metafísica que se apresenta na sentença nietzscheniana da "morte de Deus. Essa sentença significou, em um primeiro momento, o decreto do fim da religião e da questão de Deus na contemporaneidade. Pensou-se, dessa forma, que estaria em crise a conceitualização da substancialidade divina e a necessidade da religião para a humanidade. No entanto, a própria sentença denota que, com a "morte de Deus", tem-se o problema do fundamento do mundo e do homem, ou propriamente uma crise na tradição conceitual e argumentativa da razão ocidental. Afinal, "como conseguimos esvaziar o mar? Quem nos deu a esponja para apagar o horizonte inteiro? Que fizemos quando desligamos esta Terra do seu Sol? Para onde ele se move agora? Para onde nos movemos nós?" (NIETZSCHE, 1983, p. 121).

Essas indagações de Nietzsche permitem compreender que a "morte de Deus" evoca muito menos a questão da substancialidade ou do desaparecimento da religião, mas muito mais um "ateísmo hermenêutico" (VON HERMANN, 2004, p. 13) que remete à avaliação da metafísica como substrato teórico da teologia. Nesse sentido, o caminho assumido por Heidegger em desenvolver uma ontologia identificada com a fenomenologia em perspectiva hermenêutica (HEIDEGGER, 2008) foi aprofundado por Gadamer como filosofia hermenêutica para compreender a verdade com resultado de uma "fusão de horizontes", emergente do diálogo, concebido como um processo comunicativo de iluminação sapiencial, entre sujeitos que estão envolvidos na busca da verdade (GADAMER, 2003). Por isso, pela perspectiva hermenêutica, o projeto heideggeriano de "superação da metafísica" não visa destruir a metafísica literalmente, por ser essa "uma cadeia de montanhas irremovíveis" e por constituir a tradição do pensamento ocidental, em geral, e da teologia em particular. Trata-se, então, de redimensionar a metafísica por meio de uma ontologia fenomenológica hermenêutica, que, ao possibilitar a distinção entre verdade e expressão de verdade, 
propicia que as formulações teológicas estejam a serviço da verdade revelada, sem que se esgote o mistério subjacente nas próprias expressões dessa verdade. Resulta, assim, que a filosofia, caracterizada como ciência ontológica hermenêutica ou mesmo como "metafísica do ser" - compreendida como condição de possibilidade da experiência do ser humano no mundo e, ao mesmo tempo, abertura à revelação divina -, é partner da teologia que propicia a compreensão do homem e do mundo, concebidos como espaços da presença reveladora de Deus (RAHNER, 1975, pp. 95-118).

Além da relação com a filosofia, a teologia há de se relacionar com as demais ciências, que, por possuírem um positum, tomam como tema um ente previamente dado, com a sua respectiva região, que, tomada pré-cientificamente, está aberta para ser desvelada pela respectiva ciência. Por isso, cabe a cada ciência desvelar o seu ente, mostrar a sua realidade, compreendida a partir de um método próprio, tendo na filosofia aquele elemento subjacente que permite à ciência a sua necessária e singular precisão epistemológica e metódica. Por sua vez, a teologia também se serve de mediações científicas para desvelar a realidade do homem e do mundo, propiciando que o discurso teológico não esteja desvinculado dessa realidade. Nesse sentido, sendo o ser humano e o mundo espaços da revelação divina e de compreensão teológica de seu assunto fundamental, que é Deus, então a mediação científica, quando bem utilizada, possibilita que a teologia seja uma scientia fidei mundi et homini, porque é efetivamente capaz de articular história e escatologia, imanência e transcendência, constituindo-se contemporânea de cada época histórica (Ibidem).

Ao apropriar-se da filosofia-partner permanente - e de outras ciências com mediações de compreensão da realidade humana e cósmica, a teologia se mostra dialógica e com capacidade de desenvolver interdisciplinaridade e transdisciplinaridade no diálogo científico (FRANCISCO, 2019, № 4). Trata-se de afirmar o caráter sapiencial da teologia, que supera o fideísmo e o racionalismo, tanto em suas formas antigas como novas, e que explicita simultaneamente a fé e a razão como duas vias da revelação e elementos da verdade revelada que tornam a teologia ratio fidei, pois sua racionalidade referente à fé é sempre iluminada pela própria fé revelada. 
Constituindo-se como scientia fidei, incisiva na atualidade histórica, a teologia articula a fé - que possui eclesialidade e abertura soteriológica - com a realidade humana e cósmica, compreendida filosófica e cientificamente. Resulta, então, que a teologia desenvolve a sua inteligência acerca de Deus, sensibilizando-se pelo movimento da revelação divina na história dramática da humanidade e do universo, assumindo duas vias fundamentais: a catafática e a apofática. $\mathrm{Na}$ primeira, realiza as afirmações de Deus salvaguardando o positium da teologia - que é a fé revelada - e trazendo à tona o amor em forma de bondade e justiça divinas. Na segunda, Deus é afirmado mediante o silêncio, a contemplação de Deus à própria realidade humana e cósmica, de modo a emergir o amor em forma de misericórdia e compaixão. Desse silêncio, brota a contemplação de um Deus santo e inefável em seu mistério absocnditus et revelatus.

Tem-se, dessa maneira, a teologia positiva e a teologia negativa respectivamente como formas intelectualmente plausíveis e legítimas para fazer teologia. $\mathrm{Na}$ perspectiva sapiencial, não são duas formas desvinculadas uma da outra e podem estar juntas nas diversas formas de fazer teologia, propiciando que o pluralismo teológico, ainda que salvaguarde as diferenças de maneiras de produção teológica, seja marcado pela unidade das dimensões catafática e apofática, de modo que toda teologia, ainda que na sua singularidade formal, há de apontar para a revelação de um Deus bondoso, justo, libertador, misericordioso, compassivo, santo, inexaurível e efetivamente inefável. ${ }^{8}$

\subsection{Teologia: ciência sapiencial espiritual}

A cientificidade da teologia é marcada pela fé revelada e, por conseguinte, traz à tona uma espiritualidade, que reflete a atuação do Espírito na própria teologia e o modo de os sujeitos da teologia viverem a scientia fidei. Nesse sentido, a teologia possui espiritualidade, constitui-se espiritual e apresenta o caráter teologal da espiritualidade cristã. Para isso, desenvolve a mística teológica,

8. Exemplo dessa unidade entre catafatismo e apofatismo pode ser encontrado na teologia da libertação, especificamente nas obras ELLACURÍA, I. Conversión de la Iglesia al Reino de Dios. Para anuciarlo y realizarlo en la historia. Santander: Sal Terrae, 1984; SOBRINO, J. EI principio misericórdia. Bajar de la cruz a los pueblos crucificados. Santander: Salta Terrae, 1989; GUTIÉRREZ, G. La verdade los hará libres. Salamanca: Sígueme, 1990. 
compreendida como aquele elemento que pertence à scientia fidei para iluminar o próprio modo de fazer teologia e clarificar o modo como Deus se revela em toda a sua criação e sua autocomunicação aos seres humanos. Pela mística, o(a) teólogo(a) sente que o Espírito Santo é o sujeito fundamental da teologia, que suscita o sensus fidei da communitas fidelium e que inspira sujeitos à edificação de pensamentos filosóficos e científicos que sejam canais da revelação divina. A mística lhe propicia compreender que toda teologia, por melhor que seja a sua intelectualidade, requer atitude de genuflexão, de contemplação do mistério de Deus, de atitude de escuta da palavra de Deus, para que a palavra sobre Deus seja também um momento em que Deus fala aos seres humanos. É a mística que propicia à teologia ser uma scientia da esperança, por enxergar que a revelação de Deus é promessa-cumprimento, palavra-ação, amor que se movimenta e se torna caridade.

A mística teológica propicia compreender a ação do Espírito Santo na própria teologia, em consonância com os sujeitos humanos que produzem teologia. O Espírito Santo é compreendido teologicamente como Pessoa trinitária, que é o Amor entre o Pai e o Filho, é quem age criadoramente por vontade do Pai e por mediação do Filho, é quem vivifica o Filho, inspira a Igreja à sua edificação e ação evangelizadora e pastoral, estando presente no anúncio da palavra, nos sacramentos, nas formas sociais de evangelização e nas formas comunitárias de organização eclesial. Desse modo, o Espírito possui incidência material na vida humana, por ser real a sua presença na história da humanidade e do próprio universo (CONGAR, 1989). Mediante as ações desse Espírito, a teologia denota espiritualidade à medida que seu modo de se apresentar como scientia fidei seja status spiritualis indicativo da experiência de Deus, da compreensão que se tem de sua revelação na criação e de sua autocomunicação aos seres humanos.

Por ser espiritual e por ser a espiritualidade o modus vivendi segundo o Espírito, a teologia se apresenta como prática teórica da revelação, efetivando a sua condição de ciência sapiencial. Resulta, então, que a teologia seja uma ciência com linguagem própria, com método que desenvolve a interdisciplinaridade e a transdisciplinaridade, fazendo-se uma ciência em diálogo com outras ciências e com a filosofia, para também pensar - na mesma perspectiva dialó- 
gica, principalmente pela via hermenêutica - o pluralismo religioso e a pluralidade cultural. Nesse pluralismo, uma teologia sapiencial espiritual desenvolve uma soteriologia cristã aberta e inclusiva, dialoga com as tradições religiosas e promove o diálogo inter-religioso para inferir uma ética teológica que produza práxis histórica, em que as religiões contribuam para a edificação da fraternidade universal. (DUPUIS, 1997; DUQOC, 2008). Essa teologia respeita as diversas culturas, entende-as como espaços de "sementes do Verbo", promove a relação do cristianismo - que possui sua marca cultural para evangelizar - com as diferentes culturas, tanto em termos de aculturação quanto de enculturação, para, assim, produzir um discurso teológico evangelizador inculturado, em que o evangelho é transmitido de modo a ser compreendido como verdadeira boa notícia de Jesus Cristo (GONÇALVES, 2017, pp. 221-245).

\section{Considerações finais}

Objetivou-se neste trabalho apresentar a identidade da teologia como sabedoria que traz à tona a Veritatis Gaudium. Justificou-se esse objetivo o fato de que o contexto da pós-modernidade e o pluralismo teológico que toma conta desta época histórica exigem a necessidade de realçar a identidade da teologia, ainda que existam diversos modos de produção teológica. Para atingir esse objetivo, apresentou-se a teologia como sabedoria, fundamentada na revelação, que se desenvolve em diversas etapas e encontra o seu ápice em Jesus Cristo, sabedoria personificada de Deus. Em seguida, foram desenvolvidos elementos essenciais para a constituição de uma teologia sapiencial: a noção de sabedoria, a sapiencialidade da fé revelada na teologia e a espiritualidade que caracteriza a teologia como espiritual.

Em sua condição de scientia fidei et Dei, a teologia é sabedoria, porque o seu Logos já estava com Deus e era Deus. Assumindo a identidade sapiencial, a teologia jamais será desatualizada de sua época histórica, mas será sempre capaz de compreender os "signes des temps", para ainda que, em formas diversas, ser contemporânea e incisiva na atualidade histórica. Para isso, ela necessita de possuir um espírito de abertura para servir a verdade revelada, com uma linguagem que se renova permanentemente a fim de iluminar a realidade humana para 
o novum de Deus. A sabedoria torna a teologia humilde, capaz de dialogar com a filosofia - principalmente em sua vertente ontológico-hermenêutica e na da metafísica do ser - e outras ciências, utilizadas com mediações de compreensão da realidade humana e cósmica, e com outras tradições religiosas, compassivas com os sofredores e pobres deste mundo, e capazes de promover a vida em todas as suas dimensões.

Enfim, a teologia como sabedoria não se impõe arbitrariamente ao ser humano e ao mundo, mas brota da realidade de ambos, enquanto se abrem à revelação de Deus, que, por sua vez, é histórica e imbuída de sentido para a existência humana e para a vida de todo o universo. Por isso, a teologia sapiencial serve a verdade, que é Jesus Cristo e, por isso, é Veritatis Gaudium à medida que manifesta, em linguagem significativa, o desejo e o movimento que é feito para que os seres humanos encontrem a Luz verdadeira, a Sabedoria personificada, que revela o mistério amoroso do Pai.

\section{Referências bibliográficas}

ASURMENDI, J. O profetismo. Das origens à época moderna. São Paulo: Paulinas, 1988.

BOFF, C. Sinais dos tempos. Princípios de leitura. São Paulo: Loyola, 1979.

BOFF, C.Teoria do método teológico. Petrópolis: Vozes, 1998.

CONCILIO VATICANO II, Constituzione Dogmatica Lumen Gentium, in Actas Apostolicae Sedis, Città del Vaticano. v. 57, p. 5-67, 1965.

CONCILIO VATICANO II, Costituzione Dogmatica Dei Verbum, in Actas Apostolicae Sedis, Città deL Vaticano, v. 58, p. 817-836, 1966.

CONCILIO VATICANO II, Costituzione Pastoral Gaudium et Spes, in Actas Apostolicae Sedis, Città del Vaticano. v. 58, p. 1025-1115, 1966.

CONGAR, Y. A Palavra e o Espírito. São Paulo: Loyola, 1989.

CONGAR, Y. La Tradizione e la vita dela Chiesa. Roma: Paoline, 1983.

CROATTO, J.S. A estrutura dos livros proféticos. As releituras dentro do corpus profético, in Ribla, Petrópolis, v.35/36, p. 7-27, 2000.

DUPUIS, J. Verso uma Teologia Cristiana del pluralismo religioso. Brescia: Queriniana, 1997; DUQOC, C. O único Cristo. A sinfonia adiada. São Paulo: Paulinas, 2008. 
ELLACURÍA, I. Conversión de la Iglesia al Reino de Dios. Para anuciarlo y realizarlo en la historia. Santander: Sal Terrae, 1984.

EPISCOPADO LATINOAMERICANO, MEDELLÍN - 1968. La Iglesia en la actual transformación de América Lartina a la luz del Concilio, in Conferencias Generales: Río de Janeiro, Medellín, Puebla, Santo Domingo. Documentos Pastorales: Introducción, Textos, Indice Temático. Santiago del Chile: San Pablo, 1993, p. 82-223.

EPISCOPADO LATINOAMERICANO, PUEBLA- 1979. La evangelización en el presente y en el futuro de América Latina, in Conferencias Generales: Río de Janeiro, Medellín, Puebla, Santo Domingo. Documentos Pastorales: Introducción, Textos, Indice Temático. Santiago del Chile: San Pablo, 1993, p. 225-464.

FRANCISCO, PP. Constituição Apostólica Veritatis Gaudium. Sobre as Universidades e as Faculdades Eclesiásticas. Brasília: Edições CNBB, 2019, n. 4.

GADAMER, H.G. Verdade e Método(I). Traços fundamentais de uma hermenêutica filosófica. Petrópolis - Bragança Paulista: Vozes - Universidade São Francisco, 2003.

GLASSER, E. O processo da felicidade por Coelet. São Paulo: Paulinas, 1975.

GONÇALVES, P.S.L. A Aliança entre Javé e israel como paradigma para a efetividade da justiça, in BORGES DUARTE, I. (org.). Fios de Memória. Liber Amicorum para Fernanda Henriques. Lisboa: Húmus, 2018, p. 419-428.

Fernanda Henriques.Ontologia hermenêutica e Teologia. Aparecida: Santuário, 2011, p. 23-58.

Fernanda Henriques.. Zum Umgang mit den Modellen von Inkulturation, in KRÄMER, K. - VELLGUTH, K. (org.). Inkulturation. Gottes Gegenwart in den Kulturen. Freiburg im Breisgau: Herder, 2017, p. 221-245.

GROCHOLEWSKI, Z. A filosofia e a teologia na Universidade Católica, in Reflexão, Campinas, v. 40, n.2, p. 211-221.

GUTIÉRREZ, G. La verdade los hará libres. Salamanca: Sígueme, 1990.

GUTIÉRREZ, G. Onde dormirão os pobres? São Paulo: Paulus, 1998.

HEIDEGGER, M. Ontología. Hermenéutica de la Facticidad. Madrid: Alianza Editorial, 2008.

KIPPENBERG, H.G. Religião e formação de classes na antiga Judeia. São Paulo: Paulinas, 1988.

KLEIN, R.W. Israel no exílio. Uma interpretação teológica. São Paulo: Paulinas, 1990. 
METZ, J.B. Memoria passionais. Una evocación provocadora en una sociedade pluralista. Santander: Sal Terrae, 2007.

MOLTMANN, J. Ciência e Sabedoria. Um diálogo entre ciência natural e teologia. São Paulo: Loyola, 2007.

NIETZSCHE, F. Gaia Scienza, in Opere 1882/1895 (I). Roma: Newton, 1993, p. 23-214.

O'COLLINS, G. Fundamental Theology. New York - Mahwwah: Paulist Press, 1981.

O'COLLINS, G. Rivelazione: passato e presente, in LATOURELLE, R. (org.). Vaticano II: Bilancio \& prospetticve venticinque anni dopo: 1962/1987. Assisi: Cittadella Editrice, 1987, p. 125-135.

PAREYSON, L. Verdade e intepretação. São Paulo: Martins, 2005.

PASTOR, F.A. A lógica do Inefável. Aparecida: Santuário, 2012.

PASTOR, F.A. O discurso do método em Teologia, in GONÇALVES, P.S.L. Deus Inefável. Tratado temático do Deus da Revelação. Aparecida: Editora Santuário, 2015, p. 33-50.

RAHNER, K. Hörer des Wortes. Grundielung einer Religionphilosophie. Sämtliche Werke (IV). Benziger: Herder, 1997.

RAHNER, K. La Teologia nel dialogo interdisciplinare dele scienze, in Nuovi Saggi (V). Roma: Paoline, 21975, p. 119-138.

RAHNER, K. Sul rapporto odierno tra Filosofia e Teologia, in Nuovi Saggi (V). Roma: Paoline, 21975, p. 95-118.

RAVASI, G. Cântico dos Cânticos. São Paulo: Paulinas, 1988.

RICHARD, P. Nossa luta é contra os ídolos, in CROATTO, J.S. et alii. A luta dos deuses. São Paulo: Paulinas, 1985.

RUSSEL, D.S. Desvelamento divino. Uma introdução à apocalíptica judaica. São Paulo: Paulus, 1997.

SEGUNDO, J.L. Revelación, fe y signos de los tempos, in ELLACURÍA, I. SOBRINO, J. (orgs.). Mysterium Liberationis (I). Conceptos fundamentales de la Teología de la Liberación. Madrid: trotta, 1990, p. 443-466.

SHREINER, J. - DAUTZENBERG, G. Forma e exigências do novo testamento. São Paulo: Paulus - Teológica, 2004.

SICRE, J.L. As tradições históricas de Israel. Introdução à história do Antigo Testamento. Petrópolis: Vozes, 1999.

SMITH, M.S. O memorial de Deus. História, memória e a experiência do divino no Antigo Israel. São Paulo: Paulus, 2006. 
SOARES, S.A.G., Reler os profetas (notas sobre a releitura da Profecia Bíblica), in Estudos Bíblicos, Petrópolis, v. 4, p. 8-32, 1986.

SOBRINO, J. EI principio misericórdia. Bajar de la cruz a los pueblos crucificados. Santander: Sal Terrae, 1989.

TAMAYO-ACOSTA, J.J. Otra teologia es posible. Pluralismo religioso, interculturalidad y feminismo. Madrid: Herder, 2011; IDEM. Nuevo paradigma teológico. Madrid: Trotta, 2004.

TERRIEN, S. Jó. São Paulo: Paulus, 1994.

VON HERMANN, F.W. Die Metaphysik im Denken Heideggers. Città del Vaticano: Urbaniana, 2004.

ZIENER, G. A sabedoria do oriente antigo como ciência da vida. Nova compreensão e crítica de Israel à sabedoria, in SCHREINER, J. (org.). Palavra e Mensagem. São Paulo: Paulinas, 1978, p. 363-381. 